\title{
Early changes in prostaglandin concentrations in ovine maternal and fetal plasma, amniotic fluid and from dispersed cells of intrauterine tissues before the onset of ACTH-induced pre-term labour
}

\author{
D. M. Olson*, S. J. Lye*, Karolina Skinner* and J. R. G. Challis*
}

M.R.C. Group in Reproductive Biology, The University of Western Ontario, Departments of Obstetrics \& Gynaecology, and of Physiology, University Hospital, 339 Windermere Road, London,

Ontario, Canada N6A 5 A5

\begin{abstract}
Summary. The changes with time in intrauterine tissue production and concentrations of PGE-2, PGF-2 $\alpha$, 6-keto PGF-1 $\alpha$ and PGFM (13,14-dihydro-15-keto PGF-2 $\alpha$ ) in maternal and fetal plasma and amniotic fluid were investigated during the first $72 \mathrm{~h}$ of pulsatile administration of $\mathrm{ACTH}_{1-24}$ to chronically catheterized fetal sheep.

By $72 \mathrm{~h}$ there were no changes in the frequency, maximum amplitude or duration of uterine contractions compared to preinfusion values. Basal concentrations of PGE-2 in maternal and fetal plasma were generally higher than those of PGF-2 $\alpha$, while 6-keto PGF- $1 \alpha$ values were intermediate. The concentrations of all PGs increased in amniotic fluid during ACTH infusion. In fetal plasma and in maternal vena caval plasma, however, there were significant increases only in PGF-2 $\alpha$ and PGFM. No changes were observed in plasma concentrations for any $\mathrm{PG}$ during saline infusion. The mean output of PGE-2, PGF- $2 \alpha$ and 6-keto PGF-1 $\alpha$ by dispersed cells prepared from chorioallantois and fetal and maternal cotyledons was consistently higher after ACTH for $72 \mathrm{~h}$ than from saline-infused animals, although significance $(P<0.05)$ was achieved only for PGE-2 in chorioallantois. There are 3 conclusions. (1) Increases in ovine intrauterine tissue PG production precede the occurrence of increased myometrial contractile activity after ACTH treatment of fetal sheep. The results imply a causal relationship between rising $P G$ and later myometrial contractions, rather than $P G$ changes resulting from enhanced uterine activity. (2) The major site(s) of increased PG output in vitro from endogenous precursors are fetal structures, especially the chorioallantoic membranes. (3) Although PGE-2 may be the major circulating PG during late gestation, there is a selective increase in plasma PGF- $2 \alpha$ concentrations before the onset of delivery.
\end{abstract}

\section{Introduction}

Several studies have shown clearly that prostaglandins (PG) increase in ovine maternal and fetal plasma and amniotic fluid during normal parturition (Currie, Wong, Cox \& Thorburn, 1973; Flint. Anderson, Patten \& Turnbull, 1974; Challis, Dilley, Robinson \& Thorburn, 1976; Mitchell, Ellwood, Anderson \& Turnbull, 1978; Rawlings \& Ward, 1978) and during ACTH- or

* Present address: The Research Institute, St Joseph's Hospital, 268 Grosvenor Street, London, Ontario, Canada N6A 4V2.

(C) 1984 Journals of Reproduction \& Fertility Ltd 
dexamethasone-induced pre-term labour and parturition (Liggins \& Grieves, 1971; Thorburn, Nicol, Bassett, Shutt \& Cox, 1972; Currie et al., 1973; Mitchell, Flint \& Turnbull, 1976; Kendall et al., 1977; Mitchell et al., 1978). Prostaglandin F-2 $\alpha$ is known to stimulate myometrial contractile activity in sheep and promote pre-term labour (Liggins, Fairclough, Grieves, Kendall \& Knox, 1973; Mitchell et al., 1977a), while suppression of PG biosynthesis delays the onset of dexamethasone- or ACTH-induced pre-term delivery (Mitchell \& Flint, 1978a; Evans, Kennedy, Patrick \& Challis, 1982b).

Although it is apparent that PGs play a regulatory role in parturition in sheep, the temporal relationships between PG production, reflected by concentrations in amniotic fluid, maternal or fetal plasma, and the evolution of uterine contractile activity have not been clearly established. Flint et al. (1974) have indicated that maternal utero-ovarian or vena caval plasma PGF levels increased before the onset of labour, but in other studies in which such correlations have been attempted the results have been contradictory or equivocal (Liggins \& Grieves, 1971; Currie et al., 1973; Rawlings \& Ward, 1978). However, in none of these studies were the relative patterns of PGI-2 concentrations (as measured by 6-keto PGF-1 $\alpha$ ), which has been shown to inhibit ovine myometrial activity (Lye \& Challis, 1982), in the maternal and fetal plasma and amniotic fluid compared to the concentrations of the stimulatory PGs.

When $\mathrm{ACTH}_{1-24}$ is administered as pulses to fetal sheep in an attempt to simulate the probable secretion pattern from the pituitary of the fetal lamb (Jones, 1979), labour-like uterine contractions of greater than $10 \mathrm{mmHg}$ intrauterine pressure are consistently produced and ewes bearing single fetuses deliver their lambs in $99 \cdot 0 \pm 4 \cdot 1 \mathrm{~h}$ (Lye, Sprague, Mitchell \& Challis, 1983). In the present study we examined the concentrations of different prostaglandins in maternal and fetal plasma and amniotic fluid to establish whether changes occurred before alterations in the pattern of myometrial activity. We sought in-vitro evidence of enhanced PG production, and attempted to identify the major source of PG output after $72 \mathrm{~h}$ of intra-fetal ACTH treatment.

\section{Materials and Methods}

Animal preparation. The sheep used were of mixed breeds. Gestational ages were calculated from the time of insemination and verified by crown-rump length of the fetuses at the time of delivery.

Surgery was performed between Days 114 and 118 as previously described (Lye et al., 1983). Catheters were inserted into the maternal femoral artery and femoral vein such that blood was sampled from the maternal dorsal aorta and inferior vena cava, cranial to the junction of the uteroovarian vein. Vinyl catheters were introduced into a fetal carotid artery and jugular vein for sampling and infusion, and into the amniotic fluid cavity for recording intrauterine pressure as well as sampling amniotic fluid (Lye et al., 1983). Samples of fetal arterial blood (2 ml), maternal arterial and vena caval blood $(5 \mathrm{ml})$ and amniotic fluid $(5 \mathrm{ml})$ were taken, beginning on Day 125 of gestation at $08: 00 \mathrm{~h}$. Sampling was continued at 8-h intervals for the next $120 \mathrm{~h}$. Beginning on Day $127,48 \mathrm{~h}$ into the sampling protocol, the fetuses of experimental animals $(\mathrm{N}=4)$ received $\mathrm{ACTH}_{1-24}$ (Cortrosyn: Organon Pharmaceuticals, Toronto, Canada) administered as short pulse infusions $(\mathrm{ACTH})$ at the rate of $66.7 \mathrm{ng} / \mathrm{min}$ for $15 \mathrm{~min}$ every $2 \mathrm{~h}$ in $0.5 \mathrm{ml}$ saline $(9 \mathrm{~g} \mathrm{NaCl} / \mathrm{l})$. Control animals $(\mathrm{N}=4)$ were infused with saline at the same rate of $0.5 \mathrm{ml} / 15 \mathrm{~min}$. Infusions were made into the fetal jugular vein. After $72 \mathrm{~h}$ of ACTH or saline infusion, the animals were killed and tissues collected (Evans et al., 1981) for cell dispersion and in-vitro experiments.

Plasma extraction and radioimmunoassay. Blood and amniotic fluid samples were collected into heparinized plastic syringes, transferred to chilled plastic tubes, and centrifuged at $4^{\circ} \mathrm{C}$ for $10 \mathrm{~min}$ at $1500 \mathrm{~g}$. The plasma or amniotic fluid was removed and stored at $-20^{\circ} \mathrm{C}$. For assay, samples were thawed to $4^{\circ} \mathrm{C}$, aliquants of the fluid were transferred into extraction tubes and the samples were acidified to $\mathrm{pH} 3-3.5$ with $1 \mathrm{~N}-\mathrm{HCl}$. 
Radioimmunoassays were performed as described previously (Evans et al., 1981; Olson, Skinner \& Challis, 1983) except that $100 \mu \mathrm{l}$ of sample and standard were used. $\left[{ }^{3} \mathrm{H}\right] \mathrm{PGE}-2$ or [ $\left.{ }^{3} \mathrm{H}\right]$ PGFM (1000-2000 c.p.m.) was added to each sample as a recovery marker. Samples were then extracted twice with 4 volumes of diethyl ether. The organic phase was separated from the aqueous and evaporated to dryness under $\mathbf{N}_{2}$. Samples were reconstituted in phosphate-buffered saline with gelatin $(1 \mathrm{mg} / \mathrm{ml})$ and frozen until assayed. A new antiserum was raised in rabbits against PGE-2 and validation of its use for radioimmunoassay is presented here. Because of the high specificity of this antiserum, results are expressed as PGE-2.

Characterization of $P G$ radioimmunoassays. Prostaglandins were added to plasma from ovariectomized ewes to determine coefficients of variation and recovery equations as shown in Table 1. Cross-reactivities of the antisera to PGF-2 $\alpha$, 6-keto PGF-1 $\alpha$ and PGFM have been described by Evans et al. (1983), Olson \& Hertelendy (1981) and Cornette, Harrison \& Kirton (1974) respectively. Additional cross-reactivities for the 6-keto PGF- $1 \alpha$ antiserum are presented in Table 2(a). The cross-reactivities of the PGE-2 antiserum, used at a final dilution of $1: 4500$, are given in Table $2(\mathrm{~b})$.

Table 1. Characteristics of prostaglandin radioimmunoassays

\begin{tabular}{|c|c|c|c|c|c|c|}
\hline \multirow[b]{3}{*}{ PG } & \multirow{3}{*}{$\begin{array}{l}\text { Sensitivity* } \\
\text { (pg) }\end{array}$} & \multicolumn{4}{|c|}{ Coefficients of variation $(\%) \dagger$} & \multirow[b]{3}{*}{ Recovery equation $\ddagger$} \\
\hline & & \multicolumn{2}{|c|}{ Intra-assay } & \multicolumn{2}{|c|}{ Interassay } & \\
\hline & & $500 \mathrm{pg}$ & $2000 \mathrm{pg}$ & $500 \mathrm{pg}$ & $2000 \mathrm{pg}$ & \\
\hline PGE-2 & $<5$ & 3.9 & $6 \cdot 0$ & $4 \cdot 8$ & $6 \cdot 9$ & $\begin{array}{l}y=1.10 x-30 \\
r=0.993, P<0.001\end{array}$ \\
\hline PGF- $2 \alpha$ & $<5$ & $7 \cdot 6$ & $5 \cdot 2$ & $10 \cdot 3$ & $1 \cdot 8$ & $\begin{array}{l}y=0.95 x-23 \\
r=0.999, P<0.001\end{array}$ \\
\hline PGFM & $<5$ & $8 \cdot 1$ & $3 \cdot 5$ & $4 \cdot 2$ & $6 \cdot 4$ & $\begin{array}{l}y=1.02 x-27 \\
r=0.996, P<0.001\end{array}$ \\
\hline 6-keto PGF-1 $\alpha$ & $<5$ & $11 \cdot 0$ & 6.9 & $15 \cdot 3$ & $10 \cdot 7$ & $\begin{array}{l}y=0.85 x-18 \\
r=0.989, P<0.001\end{array}$ \\
\hline
\end{tabular}

\footnotetext{
* Greater than 2 standard deviations from $\mathrm{B}_{0}$.

$\dagger \mathrm{N}=4$ for each determination (s.d./mean $\times 100 \%$ ).

$\ddagger y=\mathrm{m} x+\mathrm{b}$ where $x=$ slope, $\mathrm{b}=y$ intercept in $\mathrm{pg}$, endogenous concentration subtracted.
}

Cell dispersal and incubation. Dispersed cells were prepared from the amnion, chorioallantois and the fetal and maternal portions of the cotyledons after manual separation, using procedures described elsewhere (Olson et al., 1983). We recognize that complete separation of maternal and fetal components of the placenta was not achieved using this method. Nevertheless, each portion did contain cells originating from mostly maternal or mostly fetal sources. PG output in the absence of exogenous arachidonic acid was determined for an 8-h incubation period in Eagle's Minimum Essential Medium (Olson et al., 1983). The incubations were terminated by freezing at $-70^{\circ} \mathrm{C}$. After subsequent thawing to $4^{\circ} \mathrm{C}$ and centrifugation $(1500 \mathrm{~g}, 10 \mathrm{~min})$ PGs were measured directly from the incubation medium as previously described and validated (Olson et al., 1983). Cell viability ranged from $78 \pm 5 \%$ for amnion to $89 \pm 2 \%$ for maternal cotyledons before incubation. Results are expressed as the net output of PG (pg/105 cells/8 h) into the incubation medium.

Statistical analysis. Measurements for each PG within each fluid during saline or ACTH administration were assessed by regression analyses of variance which fit linear, polynomial and exponential equations to each data set. When the best fit equation generated a significant regression $(P<0.05)$, the concentrations of PGs within that fluid were considered to have changed as a function of the time of infusion. In the results section, all ordinate intercepts are given in $\mathrm{pg} / \mathrm{ml}$. 
Table 2. Antibody cross-reactivity characteristics* for (a) anti-6-keto PGF-1 $\alpha$ serum at $50 \%$ displacement of ${ }^{125} \mathrm{I}$-histamine-6-keto PGF-1 $\alpha$ and (b) anti-PGE-2 serum at $50 \%$ displacement of $\left[{ }^{3} \mathrm{H}\right]$ PGE-2

\begin{tabular}{lcc}
\hline \multicolumn{1}{c}{ Substance } & $\begin{array}{c}\% \\
\text { cross-reaction }\end{array}$ \\
\hline (a) 6-keto PGF-1 $\alpha$ & & $100 \cdot 0$ \\
6-keto PGE-1 & $8 \cdot 8$ \\
PGI-2 Na salt & & $125 \cdot 0$ \\
PGI-2 methyl ester & & $177 \cdot 0$ \\
6 $\alpha$-Carba PGI-2 & & $10 \cdot 5$ \\
\hline & PGE-2 & $100 \cdot 0$ \\
(b) & PGE-1 & $1 \cdot 6$ \\
& PGA-2 & 0.46 \\
& PGB-1 & 0.001 \\
& PGF-1 $\alpha$ & $0 \cdot 7$ \\
& PGF-2 $\alpha$ & $2 \cdot 0$ \\
& 6-Keto PGE-1 & $2 \cdot 7$ \\
6-Keto PGF-1 $\alpha$ & $2 \cdot 2$ \\
15-Keto PGE-1 & 0.46 \\
15-Keto PGE-2 & $1 \cdot 1$ \\
15-Keto PGF-2 $\alpha$ & $0 \cdot 04$ \\
& $0 \cdot 02$ \\
13,14-Dihydro-15-Keto PGA-1 & 0.04 \\
13,14-Dihydro-15-Keto PGE-1 & 0.04 \\
13,14-Dihydro-15-Keto PGF-2 $\alpha$ & \\
\hline
\end{tabular}

* Ratio of mass of competing PG required to displace $50 \%$ of appropriate radioactive trace compared to (a) 6keto PGF-1 $\alpha$ or (b) PGE-2.

\section{Results}

Intrauterine pressure

Intrauterine pressure tracings of pregnant and parturient sheep typically display type $A$ or type $B$ activity patterns (Lye et al., 1983; Text-fig. 1). Type $A$ patterns are subdivided into $A_{1}$ and $A_{2}$ classifications. Type $A_{1}$ contractions are characterized by sustained increased of pressure of more than $5 \mathrm{~min}$ duration but less than $10 \mathrm{mmHg}$ pressure increase above baseline. As delivery becomes imminent, type $A_{1}$ contractions evolve into type $A_{2}$ contractions in which a cyclical component of activity is superimposed upon the sustained pressure increases. Type $B$ contractions occur during labour and are characterized by frequent pressure increases, of $10 \mathrm{mmHg}$ or more above baseline, which are of short duration $(<5 \mathrm{~min}$ but $>1 \mathrm{~min}$ ).

None of the animals in which the fetus received ACTH displayed any type $A_{2}$ or $B$ intrauterine pressure activity. There were no significant changes in any of the type $A_{1}$ contraction characteristics during ACTH administration (Table 3).

\section{Prostaglandin concentrations}

Maternal aorta. Neither saline nor ACTH infusion stimulated increases in any of the PGs measured in maternal aortic plasma (Text-fig. 2a).

Maternal vena cava. No changes were observed in PGE- 2 or 6-keto-PGF- $1 \alpha$ concentrations in maternal vena caval plasma during ACTH or saline administration. Both PGF- $2 \alpha(y=12 x+334$, $P<0.05)$ and PGFM $(y=38 x+1839, P<0 \cdot 01)$ levels increased in ACTH-infused animals, but there was no effect of saline infusion (Text-fig. $2 b$ ). 

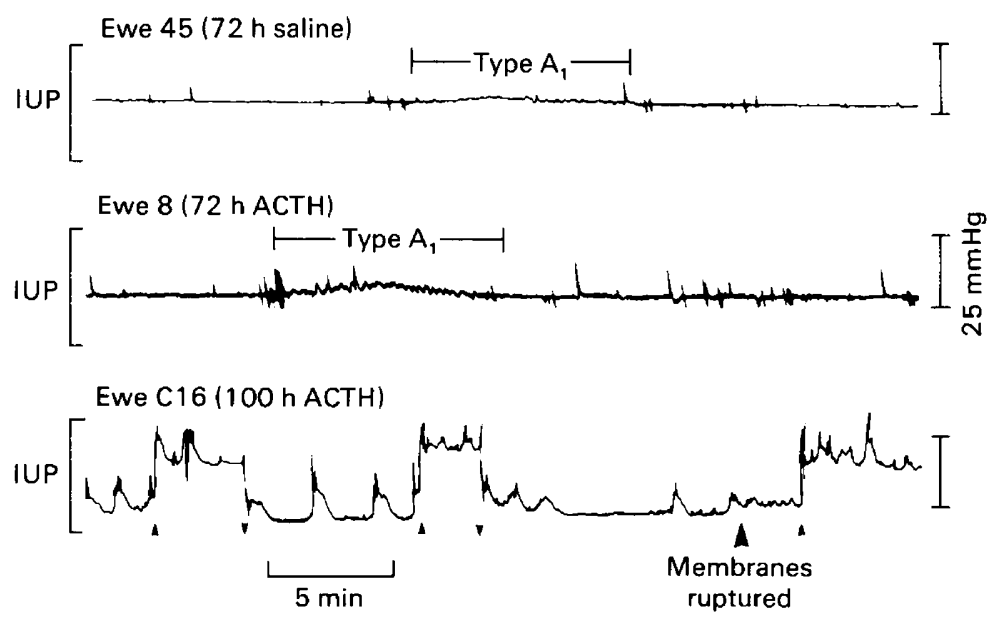

Text-fig. 1. Intrauterine pressure (IUP) records from 2 sheep after $72 \mathrm{~h}$ treatment with saline (Ewe 45) or ACTH (Ewe 8) showing the absence of any uterine contractions typical of labour. However, low amplitude (3-4 $\mathrm{mmHg}$ ) increases in intrauterine pressure of about 6-8 $\mathrm{min}$ in duration (designated type $A_{1}$ contractions) were present before and during the treatment period. Also shown is the IUP record from a $3 \mathrm{rd}$ animal (Ewe $\mathrm{Cl6}$ ) in which ACTH treatment was continued until short $(\sim 1 \mathrm{~min})$ contractions of higher amplitude typical of labour (designated type B contractions) were present. Arrows indicate when the animals stood $(\boldsymbol{A})$ or sat down $(\boldsymbol{\nabla})$.

Table 3. Intrauterine pressure type $A_{1}$ activity $12 \mathrm{~h}$ before the start and during the last $12 \mathrm{~h}$ of administration of ACTH

\begin{tabular}{cccc}
\hline $\begin{array}{c}\text { Time relative } \\
\text { to start of } \\
\text { ACTH }\end{array}$ & Frequency/2 h & $\begin{array}{c}\text { Maximum } \\
\text { amplitude } \\
\text { (mmHg) }\end{array}$ & $\begin{array}{c}\text { Duration } \\
\text { (min) }\end{array}$ \\
\hline-12 to $0 \mathrm{~h}$ & $2.29 \pm 0.42$ & $4.56 \pm 0.356 .61 \pm 0.21$ \\
+60 to $+72 \mathrm{~h}$ & $2.0 \pm 0.0$ & $4.21 \pm 0.40$ & $6.29 \pm 0.08$ \\
\hline
\end{tabular}

Values are mean \pm s.e.m. for 4 sheep.

There were no significant differences $(P>0.05)$ between the two times for any one of the 3 measures (paired $t$ tests).

Fetal carotid artery. In neither group was there any effect upon PGE-2 or 6-keto PGF-1 $\alpha$ concentrations in fetal arterial plasma. PGF- $2 \alpha$ and PGFM concentrations did not change significantly during saline administration but ACTH infusion stimulated a significant increase in the concentrations of PGF- $2 \alpha(y=5.6 x+202, P<0.05)$ and PGFM $\left(y=1824 \mathrm{e}^{(0.0011 x)}, P<\right.$ 0.05 ) (Text-fig. 2c).

Amniotic fluid. In ACTH-treated animals, there were significant increases in the concentrations of all PGs in amniotic fluid (PGE-2, $y=1029 \mathrm{e}^{(0.011 x)}, P<0.01 ; 6$-keto PGF-1 $\alpha, y=1192 \mathrm{e}^{(0.011 x)}$, $P<0.05$; PGF-2 $\alpha, y=1410 \mathrm{e}^{(0.015 x)}, P<0.01$; PGFM, $y=2545 \mathrm{e}^{(0.009 x)}, P<0.05$ ) (Text-fig. 2d). There were no significant changes in PGE-2, PGF-2 $\alpha$ or PGFM concentrations in amniotic fluid during saline infusion. However, there was a slight increase in 6-keto PGF-1 $\alpha$ concentrations $\left(y=964 \mathrm{e}^{(0.004 x)}, P<0.05\right)$ during saline administration. The 6-keto PGF-1 $\alpha$ concentrations in both groups of sheep were analysed using nested analysis of variance, in which variation was divided between hormone treatment, sheep and time of infusion. There was a significant difference $(P<0.01)$ between ACTH- and saline-treated animals at $72 \mathrm{~h}$ of infusion (Duncan's New Multiple Range Test); ACTH treatment significantly increased the mean concentration of 6-keto PGF-1 $\alpha$ in 


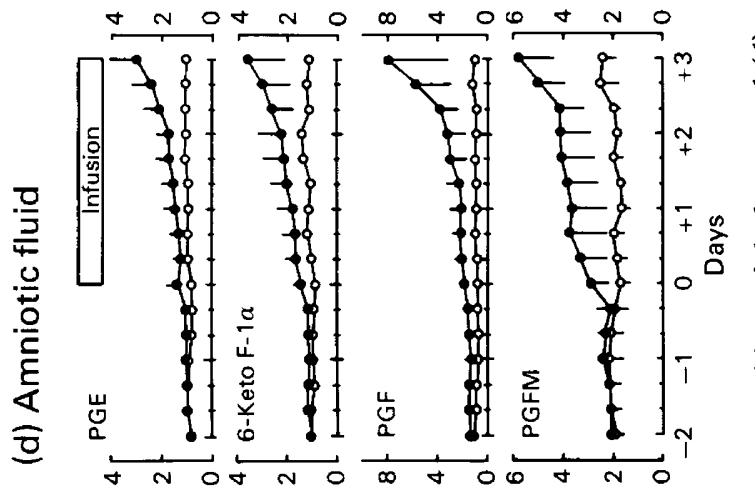

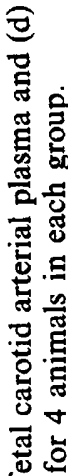

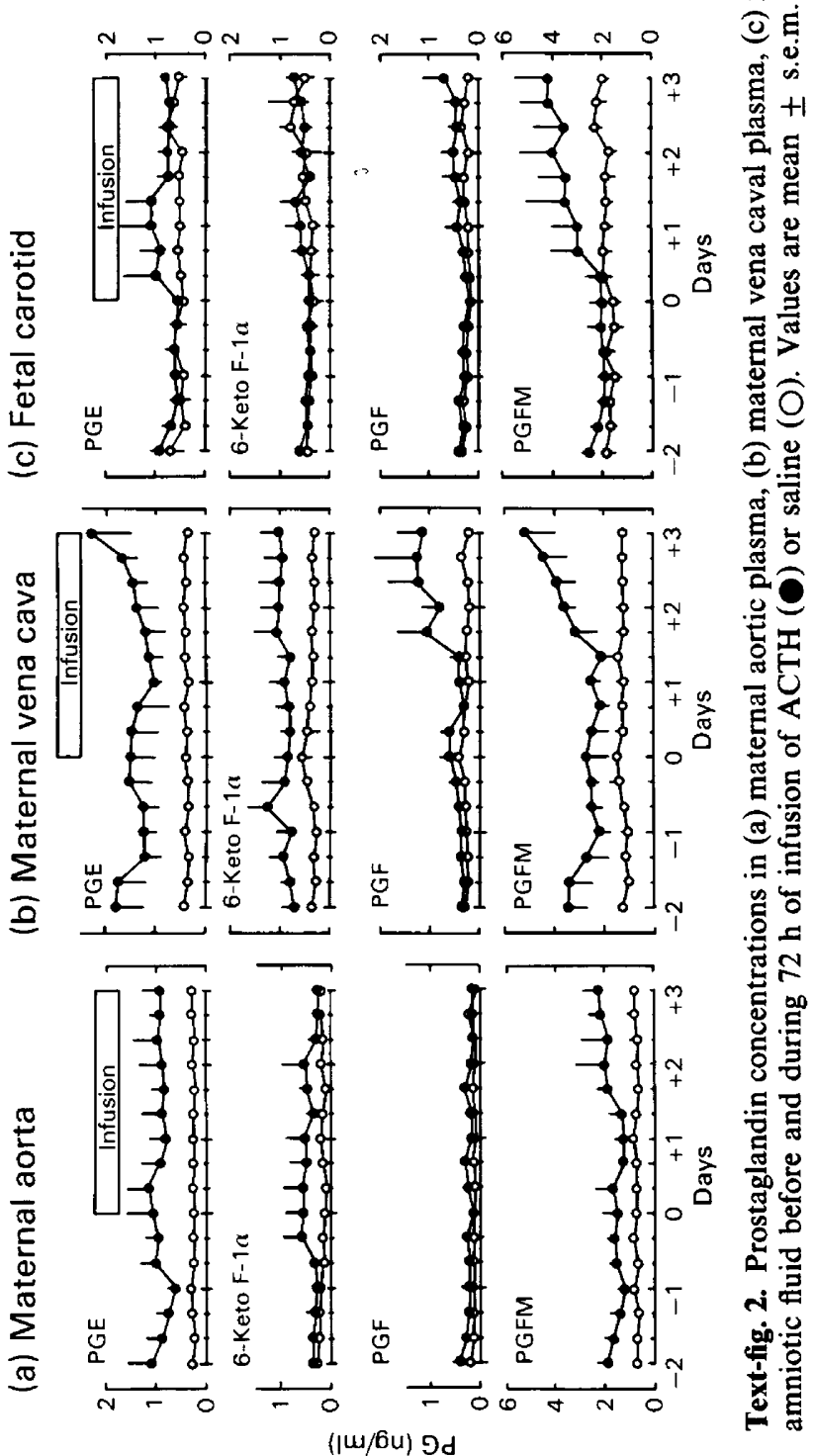


amniotic fluid and the value at $72 \mathrm{~h}$ was significantly greater $(P<0.05)$ than at $48 \mathrm{~h}$ and earlier. This was also reflected in the greater rate of time-dependent increase than that present during saline infusion (exponent $=0.011 x$ for ACTH compared to $0.004 x$ for saline). There were no significant differences between any of the mean 6-keto PGF-1 $\alpha$ concentrations during saline infusion.

Relative PG concentrations. Table 4 shows the mean concentrations of PGs after $72 \mathrm{~h}$ of infusion in all 4 fluids examined in this study. Since no significant changes occurred in the mean values of PG concentrations during the course of saline infusion, the 72-h saline values also reflect the concentrations in this group before the start of the infusion. PGE-2 was present initially in the highest concentration in maternal and fetal plasma with lower concentrations of PGF- $2 \alpha$ and intermediate values for 6-keto PGF-1 $\alpha$. In amniotic fluid from 72-h saline-infused animals, all mean PG concentrations were similar to those at the start of infusion, whereas after $72 \mathrm{~h}$ of ACTH the concentrations of PGF- $2 \alpha$ in amniotic fiuid were consistently higher than those of PGE- 2 . In the ACTH-treated animals at $72 \mathrm{~h}$ the ratio of PGE-2/PGF-2 $\alpha$ was $0.54 \pm 0.12$ compared to $1.26 \pm$ $0 \cdot 16(P<0.02$, paired $t$ test $)$ in the saline-treated animals.

Table 4. Prostaglandin concentrations $(\mathrm{pg} / \mathrm{ml})$ in the maternal aorta, vena cava, fetal carotid artery and in amniotic fluid after $72 \mathrm{~h}$ administration of $\mathrm{ACTH}$ or saline to fetal sheep

\begin{tabular}{llcccc}
\hline \multicolumn{1}{c}{ Infusion } & Aorta & Vena cava & $\begin{array}{c}\text { Fetal } \\
\text { carotid }\end{array}$ & $\begin{array}{c}\text { Amniotic } \\
\text { Fluid }\end{array}$ \\
\hline ACTH PGE-2 & $957 \pm 326$ & $2294 \pm 779$ & $812 \pm 85$ & $3012 \pm 1119$ \\
& 6-Keto PGF-1 $\alpha$ & $280 \pm 101$ & $1032 \pm 341$ & $731 \pm 166$ & $3582 \pm 1494$ \\
& PGF-2 $\alpha$ & $152 \pm 38$ & $1127 \pm 499$ & $695 \pm 431$ & $8033 \pm 4948$ \\
& PGFM & $2268 \pm 502$ & $5218 \pm 1266$ & $4164 \pm 1333$ & $5799 \pm 1401$ \\
Saline & PGE-2 & $301 \pm 50$ & $350 \pm 71$ & $547 \pm 140$ & $1029 \pm 198$ \\
& 6-Keto PGF-1 $\alpha$ & $186 \pm 80$ & $308 \pm 59$ & $511 \pm 194$ & $1135 \pm 163$ \\
& PGF-2 $\alpha$ & $100 \pm 18^{* * *}$ & $203 \pm 47^{* *}$ & $217 \pm 116^{*}$ & $841 \pm 163$ \\
& PGFM & $707 \pm 167$ & $1167 \pm 279$ & $1967 \pm 262$ & $2428 \pm 527$ \\
\hline
\end{tabular}

Values are mean \pm s.e.m. for 3 or 4 sheep.

Significantly less than PGE-2 values (paired $t$ test) ${ }^{*} P<0.05 ;{ }^{* *} P<0.02,{ }^{* * *} P<0.01$.

Table 5. Prostaglandin output $\left(\mathrm{pg} / 10^{5}\right.$ cells $/ 8 \mathrm{~h}$ ) by dispersed cells from sheep intrauterine tissues

\begin{tabular}{|c|c|c|c|c|c|}
\hline PG & Treatment & Amnion & $\begin{array}{l}\text { Chorio- } \\
\text { allantois }\end{array}$ & $\begin{array}{l}\text { Fetal } \\
\text { cotyledon }\end{array}$ & $\begin{array}{l}\text { Maternal } \\
\text { cotyledon }\end{array}$ \\
\hline \multirow[t]{2}{*}{ PGE-2 } & Saline & $\begin{array}{c}470 \pm 250 \\
(2 \cdot 18 \pm 0.48)\end{array}$ & $\begin{array}{c}161 \pm 85 \\
(1.84 \pm 0.37)\end{array}$ & $\begin{array}{c}121 \pm 55 \\
(1.85 \pm 0.29)\end{array}$ & $\begin{array}{c}505 \pm 263 \\
(2 \cdot 32 \pm 0 \cdot 42)\end{array}$ \\
\hline & ACTH & $\begin{array}{c}809 \pm 249 \\
(2 \cdot 84 \pm 0 \cdot 15)\end{array}$ & $\begin{array}{l}1052 \pm 388 \\
(2 \cdot 90 \pm 0 \cdot 21)^{*}\end{array}$ & $\begin{array}{c}633 \pm 240 \\
(2 \cdot 69 \pm 0.25)\end{array}$ & $\begin{array}{l}1069 \pm 656 \\
(2 \cdot 79 \pm 0 \cdot 25)\end{array}$ \\
\hline \multirow[t]{2}{*}{ PGF- $2 \alpha$} & Saline & $\begin{array}{c}876 \pm 507 \\
(2 \cdot 24 \pm 0.58)\end{array}$ & $\begin{array}{c}223 \pm 159 \\
(1.67 \pm 0.61)\end{array}$ & $\begin{array}{c}172 \pm 112 \\
(1.49 \pm 0.62)\end{array}$ & $\begin{array}{c}319 \pm 158 \\
(1.90 \pm 0.65)\end{array}$ \\
\hline & ACTH & $\begin{array}{c}409 \pm 117 \\
(1.57 \pm 0 \cdot 11)\end{array}$ & $\begin{array}{c}369 \pm 80 \\
(2 \cdot 52 \pm 0 \cdot 13)\end{array}$ & $\begin{array}{c}217 \pm 54 \\
(2 \cdot 30 \pm 0.13)\end{array}$ & $\begin{array}{c}580 \pm 271 \\
(2 \cdot 61 \pm 0 \cdot 21)\end{array}$ \\
\hline \multirow[t]{2}{*}{ 6-Keto PGF-1 $\alpha$} & Saline & $\begin{array}{c}369 \pm 210 \\
(1.93 \pm 0.54)\end{array}$ & $\begin{array}{c}180 \pm 108 \\
(1.84 \pm 0 \cdot 39)\end{array}$ & $\begin{array}{c}83 \pm 22 \\
(1.87 \pm 0.12)\end{array}$ & $\begin{array}{c}528 \pm 244 \\
(1.08 \pm 0.70)\end{array}$ \\
\hline & ACTH & $\begin{array}{c}342 \pm 147 \\
(2 \cdot 29 \pm 0 \cdot 66)\end{array}$ & $\begin{array}{c}699 \pm 269 \\
(2 \cdot 71 \pm 0 \cdot 23)\end{array}$ & $\begin{array}{c}137 \pm 59 \\
(2 \cdot 22 \pm 0 \cdot 14)\end{array}$ & $\begin{array}{c}575 \pm 356 \\
(2.53 \pm 0 \cdot 25)\end{array}$ \\
\hline
\end{tabular}

Values are mean \pm s.e.m. for 4 sheep. To reduce heterogeneous variance, values were transformed to common logarithms (shoy 1 fopaty theses) for statistical analysis. ${ }^{*} P<0.05$ compared to saline value (Student's $t$ 


\section{Prostaglandin output by dispersed cells}

The output of all PGs from chorioallantoic and cotyledonary cells from animals receiving ACTH infusion was consistently greater than that from saline-infused animals (Table 5). However, the wide variation between individual animals and the relatively small sample size generally eliminated statistical demonstration of these differences, except for PGE-2 output from chorioallantoic cells which was elevated significantly after ACTH treatment for $72 \mathrm{~h}(P<0.05)$.

\section{Discussion}

These results show that increases in amniotic fluid PG concentrations occurred during the first $72 \mathrm{~h}$ of ACTH administration, a segment of the labour-induction period during which no noticeable changes occurred in myometrial activity. Furthermore, these data confirm and extend the original observations of Flint et al. (1974) who reported that maternal utero-ovarian venous plasma PGF levels increased before the onset of uterine contractions. Currie et al. (1973) reported that at term the concentrations of PGF in the maternal utero-ovarian venous plasma of sheep increased slightly over basal values, corresponding to the first stage of labour. This increase began within the final $24 \mathrm{~h}$ of gestation (principally within the last 4-10 h). During the last $25 \mathrm{~min}$ of gestation this rise in PGF concentrations became more dramatic and occurred in association with second-stage labour. However, the temporal relationship of these changes with the early onset of labour-like contractions was not precisely delineated. A similar conclusion can be drawn from the work of Rawlings \& Ward (1978). Liggins \& Grieves (1971) induced labour by administering dexamethasone to fetal sheep but did not show any increase in the concentration of PGF- $2 \alpha$ in uterine venous plasma before the onset of labour, although the concentration of this PG in maternal cotyledonary tissue did increase $24 \mathrm{~h}$ before the onset of labour.

The earliest observable increase in the mechanical activity of the ovine uterus occurs within the $24 \mathrm{~h}$ before spontaneous delivery (Hindson, Schofield \& Turner, 1968; Currie et al., 1973). However, changes in the electromyographic activity of the myometrium (decreased duration and increased frequency of bursts) preceded by $10 \mathrm{~h}$ increases in mechanical activity (Harding et al., 1982). Assuming that delivery would have occurred at $100 \mathrm{~h}$ in our sheep treated with ACTH, it is apparent that increases in PG concentrations in amniotic fluid and maternal vena caval plasma preceded the earliest likely changes in myometrial electromyographic activity ( $+66 \mathrm{~h}$ of infusion). Therefore a causal relationship between PG generation and uterine contractile activity is implied by our data. Furthermore, these increases in PG production occurred earlier than may have been deduced from previous studies.

One of the primary differences between the protocol described here and other protocols used for inducing pre-term labour is the induction interval necessary to establish active labour in ewes. Our pulsatile administration of ACTH required $91 \mathrm{~h}$ in pregnancies with a single fetus to induce early labour, and another $8 \mathrm{~h}$ until active labour was established (Lye et al., 1983). A shorter infusion period, about $70 \mathrm{~h}$, is usually required to stimulate labour when greater amounts of $\mathrm{ACTH}_{1-24}(10$ $\mu \mathrm{g} / \mathrm{h} ; 20$ times the amount used here) are constantly infused to the fetus (Evans et al., 1982b). Dexamethasone (1 mg/24 h; Liggins \& Grieves, 1971) induced labour 46-52 h after infusion. In previous studies, therefore, the sequence of endocrine changes leading to induced parturition may have been compressed into a period of time too short to separate adequately the temporal relationships between individual events. Furthermore, the responsiveness of the fetal adrenal gland to ACTH in terms of cortisol output increases during the last 2 weeks of gestation and appears to be a function of the mode of ACTH administration (Glickman \& Challis, 1980; Manchester, Lye \& Challis, 1983). The temporal effects of ACTH administration upon subsequent PG production are therefore as much a function of adrenal responsiveness as mode of ACTH administration.

The major primary PG present in all plasmas was PGE-2. This confirms earlier reports stating 
that PGE was present in fetal plasma at levels greater than those of PGF (Challis et al., 1976) and that PGE-2 is present in maternal arterial plasma in concentrations greater than those of PGF- $2 \alpha$ (Mitchell, Brunt, Clover \& Walker, 1980). Our data consistently showed higher concentrations of PGE-2 than PGF- $2 \alpha$ in paired samples from maternal aortic and vena caval plasma after $72 \mathrm{~h}$ of ACTH infusion. However, due to the variation between animals, statistical significance was not demonstrable. PGE-2 levels were also significantly higher than those of PGF-2 $\alpha$ in plasma collected from saline-infused animals.

This is not the situation observed previously for animals in spontaneous labour at term. During the last hours before delivery, PGF- $2 \alpha$ concentrations in the maternal utero-ovarian vein plasma increased at a greater rate than PGE-2 such that PGF- $2 \alpha$ became the major PG in this compartment (Challis et al., 1976). Our results showing a significant increase in only PGF- $2 \alpha$ and PGFM in maternal vena caval plasma, and a significant decrease in the PGE-2/PGF- $2 \alpha$ ratio in amniotic fluid of animals receiving ACTH, parallel this earlier observation. Moreover, these early changes portend the later, greater and selective increase in the F prostaglandins. With only $72 \mathrm{~h}$ of ACTH infusion, no changes in fetal carotid arterial plasma PGE-2 levels were noted, although they did increase in animals in normal spontaneous labour at term (Challis et al., 1976). In that study PGF- $2 \alpha$ levels increased only slightly at term over values obtained earlier in gestation, not unlike changes we observed by $72 \mathrm{~h}$ of ACTH infusion. We noted, however, that the major PG change associated with ACTH treatment was PGFM, thus confirming the smaller, less perceptible increase in the primary PG. This metabolite of PGF- $2 \alpha$ was not measured in the earlier study. These observations suggest that, although synthesis of all PGs increases at term, a preferential change in prostaglandin endoperoxide metabolism towards the stimulatory PGF- $2 \alpha$ and away from the inhibitory PGI-2 (6-keto PGF-1 $\alpha$ ) might occur in selected uterine tissues before induced delivery.

The PGs present in each of the fluid compartments reflect a variety of origins. The amnion is presumably a primary source for PGs in the amniotic fluid, although PGs in fetal urine may also contribute to amniotic fluid PGs. At normal term and during induced pre-term labour, both the concentration in and the production of PGF by amnion tissue are greater than those of PGE (Evans et al., 1981 ; Evans, Kennedy \& Challis, 1982a). However, fetal urine contains higher levels of PGE than amniotic fluid but lower levels of PGF (Walker \& Mitchell, 1978), indicating that the fetus may be a primary source of amniotic fluid PGE. Due to low PG concentrations in fetal tracheal fluid, it is unlikely that this fluid contributes significantly to amniotic fluid PG concentrations (Mitchell, Robinson \& Thorburn, 1977b; Walker \& Mitchell, 1978). On the other hand, increases in amniotic fluid PG concentrations may reflect decreases or rapid fluctuations in amniotic fluid volume (Lingwood, Hardy, Long, McPhee \& Wintour, 1980) rather than increases in PG production only.

The fetus and intrauterine tissues of fetal origin are the probable sources of the high levels of PGE-2 in fetal carotid arterial plasma. The fetal cotyledons and chorioallantois are implicated by the findings presented here and by previous studies (Mitchell \& Flint, 1978b; Evans et al., 1981, 1982a). PGE is also the major product of several non-vascular fetal tissues (Pace-Asciak \& Rangaraj, 1978).

The mean output of PGE-2 by all tissues was greater after ACTH treatment, and exceeded the increment in PGF-2 $\alpha$. This pattern of PG output, which in general is similar to that from human fetal membranes in association with spontaneous labour at full term (Olson et al., 1983), differs from the pattern of rising PGF- $2 \alpha$ as well as PGE-2 in the fetal fluids and plasma of sheep after ACTH for $72 \mathrm{~h}$. This difference may reflect altered availability of co-factors in vitro and in vivo, or 9keto reductase activity in the uterine tissues, or fetal and maternal blood (Bolla, Carson \& Challis, 1977). Casey \& MacDonald (1983) have shown that addition of PGE to human endometrial cells provokes a preferential increase in the output of PGF by the tissue, consistent with 9 -keto reductase activity or directed endoperoxide metabolism. In addition, uterine venous plasma PGs reflect a composite of the effluent from different uterine and intrauterine tissues. The chorioallantois, which 
is a vascular tissue in sheep, and endometrium each produce or contain higher levels of PGF than PGE at term (Evans et al., 1981, 1982a).

In conclusion, we have shown that prostaglandin production by intrauterine tissues increases in response to fetal adrenal activation induced by ACTH administration before the onset of myometrial contractility, implying a causal relationship. While PGE-2 may be the principal circulating primary PG during late gestation in mother and fetus, the onset of labour is heralded by a selective increase in the plasma and fluid levels of PGF-2 $\alpha$.

We thank Mr Gerald Barbe, M.R.C. Group in Reproductive Biology, for preparation of the PGE-2 antiserum; Ms Cher Sprague for assistance with the sample collection; Mr Ken McGill and his staff at the U.W.O. Animal Centre for care of the animals; Mr Douglas Johnson for accurately timed pregnant sheep; and Dr K. T. Kirton, The Upjohn Company, for antiserum to PGFM. This work was supported by a Postdoctoral Fellowship from the Lalor Foundation and by a NATO Postdoctoral Fellowship in Science (D.M.O.); M.R.C. (Canada) Fellowship (S.J.L.) and M.R.C. (Canada) Group Grant (J.R.G.C.); and by grants from the Physicians' Services Incorporated of Ontario and from The Richard and Jean Ivey Fund (to J.R.G.C. and Dr J. E. Patrick).

\section{References}

Bolla, J., Carson, G.D. \& Challis, J.R.G. (1977) Conversion of $\mathrm{PGE}_{2}$ to $\mathrm{PGF}_{2 \alpha}$ by fetal sheep blood. Prostaglandins 14, 873-879.

Casey, M.L. \& MacDonald, P.C. (1983) Pisseaktis in human amniotic fluid. Endocrinology 112, Suppl. p. 230, Abstr. 600.

Challis, J.R.G., Dilley, S.R., Robinson, J.S. \& Thorburn, G.D. (1976) Prostaglandins in the circulation of the fetal lamb. Prostaglandins 11, 1041-1052.

Cornette, J.C., Harrison, K.L. \& Kirton, K.T. (1974) Measurement of prostaglandin $F_{2 \alpha}$ metabolites by radioimmunoassay. Prostaglandins 5, 155-164.

Currie, W.B., Wong, M.S.F., Cox, R.I. \& Thorburn, G.D. (1973) Spontaneous or dexamethasone-induced parturition in the sheep and goat: changes in plasma concentrations of maternal prostaglandin $\mathbf{F}$ and foetal oestrogen sulphate. M. Soc. Endocr. 20, 95-118.

Evans, C.A., Kennedy, T.G., Patrick, J.E. \& Challis, J.R.G. (1981) Uterine prostaglandin concentrations in sheep during late pregnancy and adrenocorticotropin-induced labor. Endocrinology 109, 1533-1538.

Evans, C.A., Kennedy, T.G. \& Challis, J.R.G. (1982a) Gestational changes in prostanoid concentrations in intrauterine tissues and fetal fluids from pregnant sheep, and the relation to prostanoid output in vitro. Biol. Reprod. 27, 1-11.

Evans, C.A., Kennedy, T.G., Patrick, J.E. \& Challis, J.R.G. (1982b) The effects of indomethacin on uterine activity and prostaglandin (PG) concentrations during labor induced by administering ACTH to fetal sheep. Can. J. Physiol. Pharmacol. 60, 12001209.

Flint, A.P.F., Anderson, A.B.M., Patten, P.T. \& Turnbull, A.C. (1974) Control of utero-ovarian venous prostaglandin F during labour in the sheep: acute effects of vaginal and cervical stimulation. $J$. Endocr. 63, 6787.

Glickman, J.A. \& Challis, J.R.G. (1980) The changing response pattern of sheep fetal adrenal cells throughout the course of gestation. Endocrinology 106, 13711376.
Harding, R., Poore, E.R., Bailey, A., Thorburn, G.D., Jansen, C.A.M. \& Nathanielsz, P.W. (1982) Electromyographic activity of the nonpregnant and pregnant sheep uterus. Am. J. Obstet. Gynec. 142, 448457.

Hindson, J.C., Schofield, B.M. \& Turner, C.B. (1968) Parturient pressures in the ovine uterus. J. Physiol., Lond. 195, 19-28.

Jones, C.T. (1979) Normal fluctuations in the concentration of corticosteroid and adrenocorticotrophin in the plasma of foetal and pregnant sheep. Horm. Metab. Res. 11, 237-241.

Kendall, J.Z., Challis, J.R.G., Hart, I.C., Jones, C.T., Mitchell, M.D., Ritchie, J.W.K., Robinson, J.S. \& Thorburn, G.D. (1977) Steroid and prostaglandin concentrations in the plasma of pregnant ewes during infusion of adrenocorticotrophin or dexamethasone to intact or hypophysectomized foetuses. $J$. Endocr. 75, 59-71.

Liggins, G.C. \& Grieves, S. (1971) Possible role for prostaglandin $F_{2 \alpha}$ in parturition in sheep. Nature, Lond. 232, 629-631.

Liggins, G.C., Fairclough, R.J., Grieves, S.A., Kendall, J.Z., \& Knox, B.S. (1973) The mechanism of initiation of parturition in the ewe. Recent Prog. Horm. Res. 29, 111-159.

Lingwood, B.E., Hardy, K.J., Long, J.G., McPhee, M. \& Wintour, E.M. (1980) Amniotic fluid volume and composition following experimental manipulations in sheep. Obstet. Gynecol. 56, 451-461.

Lye, S.J. \& Challis, J.R.G. (1982) Inhibition by PGI-2 of myometrial activity in vivo in non-pregnant ovariectomized sheep. J. Reprod. Fert. 66, 311-315.

Lye, S.J., Sprague, C.L., Mitchell, B.F. \& Challis, J.R.G. (1983) Activation of ovine fetal adrenal function by pulsatile or continuous administration of adrenocorticotropin-(1-24). I. Effects on fetal plasma corticosteroids. Endocrinology 113, 770-776.

Manchester, E.L., Lye, S.J. \& Challis, J.R.G. (1983) Activation of ovine fetal adrenal function by pulsatile or continuous administration of adrenocorticotropin- 
(1-24). II. Effects on adrenal cell responses in vitro. Endocrinology 113, 777-782.

Mitchell, M.D. \& Flint, A.P.F. (1978a) Use of meclofenamic acid to investigate the role of prostaglandin biosynthesis during induced parturition in sheep. $J$. Endocr. 76, 101-109.

Mitchell, M.D. \& Flint, A.P.F. (1978b) Prostaglandin production by intra-uterine tissues from periparturient sheep: use of a superfusion technique. $J$. Endocr. 76, 111-121.

Mitchell, M.D., Flint, A.P.F. \& Turnbull, A.C. (1976) Plasma concentrations of 13,14-dihydro-15-ketoprostaglandin F during pregnancy in sheep. Prostaglandins 11, 319-329.

Mitchell, M.D., Flint, A.P.F. \& Turnbull, A.C. (1977a) Stimulation of uterine activity by administration of prostaglandin F-2 $\alpha$ during parturition in sheep. $J$. Reprod. Fert. 48, 189-190.

Mitchell, M.D., Robinson, J.S. \& Thorburn, G.D. (1977b) Prostaglandins in fetal tracheal and amniotic fluid from late pregnant sheep. Prostaglandins 14, 10051011.

Mitchell, M.D., Ellwood, D.A., Anderson, A.B.M. \& Turnbull, A.C. (1978) Elevated concentrations of 6keto-prostaglandin $F_{1 \alpha}$ in fetal and maternal plasma and in amniotic fluid during ovine parturition. Prostaglandins Med. 1, 265-266.
Mitchell, M.D., Brunt, J., Clover, L. \& Walker, D.W. (1980) Prostaglandins in the umbilical and uterine circulations during late pregnancy in the ewe. $J$. Reprod. Fert. 58, 283-287.

Olson, D.M. \& Hertelendy, F. (1981) Plasma levels of 13,14-dihydro-15-keto prostaglandin $F_{2 \alpha}$ in relation to oviposition and ovulation in the domestic hen (Gallus domesticus). Biol. Reprod. 24, 496-504.

Olson, D.M., Skinner, K. \& Challis, J.R.G. (1983) Prostaglandin output in relation to parturition by cells dispersed from human intrauterine tissues. $J$. clin. Endocrinol. Metab. 57, 694-699.

Pace-Asciak, C.R. \& Rangaraj, G. (1978) Distribution of prostaglandin biosynthetic pathways in organs and tissues of the fetal lamb. Biochim. Biophys. Acta 528, 512-514.

Rawlings, N.C. \& Ward, W.R. (1978) Correlations of maternal and fetal endocrine events with uterine pressure changes around parturition in the ewe. $J$. Reprod. Fert. 54, 1-8.

Thorburn, G.D., Nicol, D.H., Bassett, J.M., Shutt, D.A. $\&$ Cox, R.I. (1972) Parturition in the goat and sheep: changes in corticosteroids, progesterone, oestrogens and prostaglandin F. J. Reprod. Fert., Suppl. 16, 6184.

Walker, D.W. \& Mitchell, M.D. (1978) Prostaglandins in urine of foetal lambs. Nature, Lond. 271, 161-162.

Received 13 July 1983 